\title{
Pengaruh Citra Koperasi, Kepercayaan Dan Kualitas Pelayanan Terhadap Kepuasan Anggota Koperasi Serba Usaha Wahyu Artha Sedana Di Gianyar
}

\author{
Ni Putu Eka Wahyu Utami ${ }^{1}$ \\ I Made Suasti Puja ${ }^{2}$ \\ ${ }^{1,2}$ Fakultas Ekonomi Bisnis dan Pariwisata, Universitas Hindu Indonesia \\ Email: ekawahyuutmi@gmail.com
}

\begin{tabular}{|l|l|l|}
\hline Diterima: 8 Desember 2020 & Direvisi: 13 Desember 2020 & Disetujui: 20 Desember 2020 \\
\hline
\end{tabular}

\begin{abstract}
The image of the cooperative, trust and service quality is one of the factors that influence member satisfaction. The purpose of this study was to determine the effect of cooperative image, trust and service quality on the satisfaction of KSU members. Wahyu Artha Sedana. The method used in this research is accidental sampling. Data collection was carried out through observation, library research, interviews and questionnaires. The analysis technique used is multiple linear regression. Based on the results of the analysis, it was found that the image of the cooperative, trust and service quality had a positive and significant effect on member satisfaction both partially and simultaneously. Based on the results obtained in this study, KSU.Wahyu Artha Sedana should pay attention to all things related to the satisfaction of cooperative members, so that each member can feel comfortable when making transactions.

Keywords: cooperative image, trust, service quality, member satisfaction
\end{abstract}

\begin{abstract}
ABSTRAK
Citra koperasi, kepercayaan dan kualitas pelayanan merupakan salah satu faktor yang mempengaruhi kepuasan anggota. Tujuan penelitian ini adalah untuk mengetahui pengaruh citra koperasi, kepercayaan dan kualitas pelayanan terhadap kepuasan anggota KSU. Wahyu Artha Sedana. Metode yang digunakan dalam penelitian ini adalah aksidental sampling. Pengumpulan data dilakukan melalui observasi, penelitian pustaka, wawancara dan kuesioner. Teknik analisis yang digunakan adalah regresi linear berganda. Berdasarkan hasil analisis ditemukan bahwa citra koperasi, kepercayaan dan kualitas pelayanan berpengaruh positif dan signifikan terhadap kepuasan anggota baik itu secara parsial dan simultan. Berdasarkan hasil yang diperoleh pada penelitian ini sudah selayaknya KSU.Wahyu Artha Sedana memperhatikan segala hal yang berkaitan dengan kepuasan anggota koperasinya, sehingga setiap anggota dapat merasakan kenyamanan pada saat melakukan transaksi.
\end{abstract}

Kata kunci : citra koperasi, kepercayaan, kualitas pelayanan, kepuasan anggota

\section{PENDAHULUAN}

Dewasa ini perusahaan dituntut untuk mampu memberikan pelayanan yang terbaik kepada pelanggannya agar dapat memenangkan persaingan bisnis yang kini semakin ketat terutama akibat dari terjadinya globalisasi sehingga memunculkan banyak peluang dan menghadirkan banyak pemain dalam suatu industri. Umumnya yang digunakan konsumen adalah aspek pelayanan dan kualitas barang dan jasa yang dibeli (Tjiptono, 2002:26). 
Faktor-faktor yang dapat mempengaruhi kepuasan anggota adalah citra koperasi, kepercayaan, dan kualitas pelayanan. Citra adalah sesuatu yang sangat penting dalam sebuah badan usaha. Istijanto, (2005) mengemukakan bahwa perusahaan yang memiliki citra atau reputasi yang baik akan mempertinggi kemampuan bersaing, mendorong semangat kerja karyawan, dan meningkatkan loyalitas anggota. Faktor kedua yaitu kepercayaan dimana kepercayan menurut Kotler \& Keller (2012 : 225) adalah kesediaan pihak perusahaan untuk mengandalkan mitra bisnis. Koperasi, sebagai salah satu lembaga keuangan terutama lembaga keuangan non bank merupakan suatu jenis usaha yang juga mengandalkan kepercayaan para anggotanya untuk tetap dapat eksis dan juga berkembang demi mensejahterakan anggotanya. Faktor ketiga yaitu kualitas pelayanan Menurut Goetsch Davis dalam Zulian Yamit (2002: 8) "Kualitas merupakan suatu kondisi dinamis yang berhubungan dengan produk, jasa, manusia, proses dan lingkungan yang memenuhi atau melebihi harapan". Apabila ketiga faktor di atas dapat berjalan dengan baik maka akan berpengaruh baik kepada kepuasan anggota.

Setelah melakukan observasi dan wawancara peneliti memperoleh informasi bahwa terjadi banyak keluhan dari anggota yang ikut dalam KSU. Wahyu Artha Sedana di Gianyar, hal tersebut dikarenakan pernah ada karyawan koperasi yang tidak melaksanakan tugasnya dengan baik yang menyebabkan berkurangnya citra koperasi di mata anggota maupun masyarakat sekitar, hal tersebut berdampak kepada turunnya kepercayaan anggota terhadap KSU. Wahyu Artha Sedana di Gianyar, Banyaknya keluhan yang diterima dari anggota koperasi menyebabkan terjadinya penurunan jumlah anggota yang ikut bergabung menjadi nasabah.

Menurunnya jumlah anggota yang ikut bergabung di KSU. Wahyu Arta Sedana juga berdampak terhadap arus keuangan koperasi seperti halnya pinjaman ataupun kredit, dalam beberapa tahun terakhir akibat dari penurunan jumlah anggota koperasi, juga terjadi penurunan terhadap aktivitas kredit. Terjadi penurunan jumlah kredit dari tahun 2014 sampai tahun 2018, yaitu pada tahun 2014 jumlah kredit mencapai Rp. 910.000.0000 kemudian tahun berikutnya mengalami penurunan hingga pada tahun 2018 peurunan kredit lumayan drastis dengan jumlah kredit di tahun 2018 yaitu Rp 480.000.000, berdasarkan informasi yang diperoleh dari pengurus penurunan terjadi disebabkan karena memang benar bahwa dalam hal pelayanan pinjaman maupun kredit pelayanannya masih belum maksimal hal tersebut terjadi karena kurangnya pelatihan dan pemahaman yang didapat oleh pengurus terkait arus pinjaman dan kredit, selain itu masyarakat atau anggota yang meminjam juga mengeluh akibat dana yang dipinjam ataupun kredit yang diberikan oleh koperasi tergolong masih rendah, oleh karena itu nasabah memilih untuk meminjam ataupun mencari kredit yang lebih besar seperti dana-dan KUR yang terdapat di 
Bank pada saat ini. Jadi kredit di KSU. Wahyu Artha Sedana beberapa tahun terakhir ini sedang mengalami arus yang tidak sehat.

Tujuan dalam penelitian ini adalah (1) untuk mengetahui pengaruh citra koperasi terhadap kepuasan anggota pada KSU. Wahyu Artha Sedana, (2) untuk mengetahui pengaruh kepercayaan terhadap kepuasan anggota pada KSU. Wahyu Artha Sedana, (3) untuk mengetahui pengaruh kualitas pelayanan terhadap kepuasan anggota pada KSU. Wahyu Artha Sedana, dan (4) untuk mengetahui pengaruh citra koperasi , kepercayaan anggota , kualitas pelayanan terhadap kepuasan anggota pada KSU. Wahyu Artha Sedana.

\section{TELAAH LITERATUR DAN HIPOTESIS}

\section{Kepuasan}

Kotler (2012) menyatakan kepuasan adalah perasaan senang atau kecewa seseorang sebagai hasil dari perbandingan antara prestasi atau produk yang dirasakan dan yang diharapkan. Menurut Oliver (dalam Supranto, 2011:233) kepuasan sebagai tingkat perasaan seseorang setelah membandingkan kinerja atau hasil yang dirasakannya dengan yang diharapkan. Secara umum kepuasan dapat diartikan sebagai perbandingan antara harapan dan kinerja. Westbrook dan Reilly (Tjiptono, 2014) mengemukakan bahwa kepuasan merupakan respon emosional konsumen terhadap pengalaman yang berkaitan dengan produk dan jasa.

\section{Citra Koperasi}

Citra (image) merupakan seperangkat keyakinan, ide, dan pesan yang dimiliki seseorang terhadap suatu Obyek, "citra (image) adalah kepercayaan, ide, dan impresi seseorang terhadap sesuatu", (Kotler, 2014). Citra dapat digambarkan melalui persepsi, kognisi, motivasi dan sikap dari seseorang sehingga pembentukan citra akan menghasilkan sikap pendapat, pendapat, tanggapan atau perilaku tertentu. Kualitas teknis dan fungsional menentukan citra korporat yang pada gilirannya dapat memenuhi kualitas jasa yang dipersepsikan anggota, (Ardianto, 2016).

\section{Kepercayaan}

Menurut Kotler \& Keller (2012 : 225) mengatakan bahwa, "Trust is the willingness of a firm to rely on a business partner. It depends on a number of interpersonal and interorganizational factors, such as the firm's perceived competence, integrity, honesty and benevolence". Kepercayaan konsumen menurut Mowen dan Minor yang dikutip oleh Sumarwan (2011) adalah pengetahuan yang dimiliki oleh konsumen mengenai suatu Obyek, atribut, dan manfaatnya. Hendia (2013:21) mengartikan kepercyaan sebagai keyakinan bahwa kata atau janji seseorang dapat dipercaya dan seseorang akan memenuhi kewajibannya dalam sebuah hubungan pertukaran. 


\section{Kualitas Pelayanan}

Dalam Kamus Besar Bahasa Indonesia (2008), kualitas didefinisikan sebagai "tingkat baik buruknya sesuatu". Kualitas dapat pula didefinisikan sebagai tingkat keunggulan, sehingga kualitas merupakan ukuran relative kebaikan. Menurut Goetsch Davis dalam Zulian Yamit (2002: 8) kualitas merupakan suatu kondisi dinamis yang berhubungan dengan produk, jasa, manusia, proses dan lingkungan yang memenuhi atau melebihi harapan.

\section{Hipotesis Penelitian}

H1 : diduga citra koperasi berpengaruh positif dan signifikan terhadap kepuasan anggota KSU. Wahyu Artha Sedana.

H2 : diduga kepercayaan berpegaruh positif dan signifikan terhadap kepuasan anggota KSU. Wahyu Artha Sedana

H3 : diduga kualitas pelayanan berpengaruh positif dan signifikan terhadap kepuasan anggota KSU. Wahyu Artha Sedana

H4 : diduga terdapat pengaruh positif dan signifikan secara bersama-sama dari citra koperasi, kepercayaan dan kualitas pelayanan terhadap kepuasan anggota KSU. Wahyu Artha Sedana.

\section{METODE PENELITIAN}

\section{Desain Penelitian}

Penelitian ini termasuk penelitian asosiatif kausal, karena penelitian ini bertujuan untuk mengetahui pengaruh variabel $\mathrm{X}$ terhadap $\mathrm{Y}$ yang bersifat kausal. Penelitian asosiatif merupakan penelitian yang bertujuan untuk mengetahui hubungan antara dua variabel atau lebih. Dalam penelitian ini mempunyai tiga variabel independen (bebas) dan satu variabel dependen (terikat). Citra koperasi sebagai variabel independen pertama (X1), kepercayaan nasabah sebagai variabel independen kedua (X2), kualitas pelayanan sebagai variabel independen ketiga (X3) dan kepuasan anggota sebagai variabel dependen (Y).

\section{Gambar 3.1}

\section{Kerangka Berpikir}




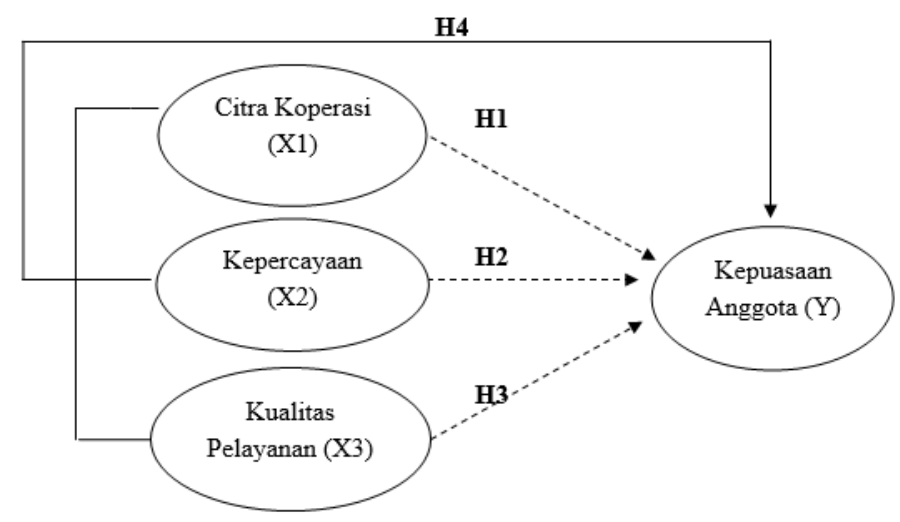

\section{Populasi dan Sampel}

Populasi dalam penelitian ini adalah keseluruhan anggota KSU. Wahyu Artha Sedana periode tahun 2018 sebanyak 121 orang dan dengan menggunakan RumuS Slovin maka ditetapkan sampel sebanyak 55 orang dengan teknik pengumpulan data aksidental sampling.

\section{Metode Pengumpulan Data}

Pengumpulan data dalam penelitian ini dilakukan dnegan mengunakan metode observasi, wawancara, studi dokumentasi, kepustakaan, dokumentasi, dan kuisioner. Dengan melakukan penyebaran kuesioner responden untuk mengukur persepsi responden digunakan skala likert. Pernyataan dalam kuesioner dibuat dengan menggunakan skala 1-5 untuk mewakili pendapat dari responden. Nilai untuk skala tersebut adalah Sangat tidak setuju diberi nilai 1, Tidak setuju diberi nilai 2, Kurang setuju diberi nilai 3, Setuju diberi nilai 4, dan Sangat setuju diberi nilai 5.

\section{Analisis Data}

1. Uji instrumen penelitian, dilakukan dengan Uji validitas dilakukan untuk mengetahui kemampuan uatu daftar pertanyaan untuk mengukur apa yang seharusnya diukur dan uji Reliabilitas bertujuan untuk mencari tahu sampai sejauh mana konsistentasi alat ukur yang digunakan sehingga bila alat ukur tersebut digunakan kembali untuk meneliti Obyek yang sama dengan tehnik yang sama walaupun waktunya berbeda, maka hasilnya yang akan diperoleh akan sama.

2. Uji asumsi klasik, terdiri atas uji normalitas, uji multikolinearitas, dan uji heteroskedastisitas.

3. Regresi linear berganda, digunakan untuk mengetahui atau memperoleh gambaran mengenai pengaruh variabel bebas terhadap variabel terikat, dengan menggunakan Statistical Package for Social Science (SPSS)

\section{HASIL PENELITIAN DAN PEMBAHASAN}

\section{Uji Instrumen Penelitian}


Berdasarkan Tabel 1 dapat dilihat bahwa nilai Sig.2 Tailed dari masing-masing pernyataan $<0,05$. Jadi dapat disimpulkan bahwa semua pernyataan adalah valid dan nilai Cronbach Alpha $(\alpha)$ pada masing-masing variabel adalah > 0,60. Jadi dapat disimpulkan variabel citra koperasi(X1), kepercayaan(X2), kualitas pelayanan(X3) dan kepuasan pelanggan(Y) sudah reliabel.

\section{Karakteristik Responden}

Responden dalam penelitian ini adalah seluruh anggota KSU Wahyu Artha Sedana tahun 2018 yang sudah diambil sampelnya yaitu sebanyak 55 responden. Karakteristik yang diteliti dalam penelitian ini meliputi jenis kelamin, umur responden, pendidikan dan masa menjadi anggota.

1. Berdasarkan jenis kelamin, terlihat bahwa 20 responden yang berjenis kelamin laki - laki dengan persentase sebesar $37 \%$ dan 35 responden yang berjenis kelamin perempuan dengan persentase sebesar 63\%. Berdasarkan data tersebut, yang menjadi anggota KSU. Wahyu Artha Sedana didominasi oleh responden berjenis kelamin perempuan.

2. Dari segi usia, responden yang berumur 25-34 tahun yaitu sebanyak 15 orang dengan persentase sebesar 28\%, responden yang berumur 35-54 tahun sebanyak 35orang dengan persentase $63 \%$ dan responden yang berumur $\geq 55$ tahun adalah sebanyak 5 orang dengan persentase sebesar $9 \%$.

3. Berdasarkan tingkat pendidikan responden terbesar berada di tingkat S1 dengan jumlah sebanyak 30 orang dengan persentase sebesar 55\%. Dari hasil tersebut dapat dilihat bahwa tingginya pendidikan menjadi salah satu dorongan untuk melakukan transaksi maupun menjadi anggota KSU. Wahyu Artha Sedana karena adanya gaji yang cenderung lebih besar.

4. Berdasarkan lama menjadi anggota, responden yang ikut menjadi anggota di KSU. Wahyu Artha Sedana $\geq 1$ tahun sebanyak 40 orang dengan persentase sebesar $73 \%$ dan sisanya $\leq 1$ tahun sebanyak 15 orang dengan persentase sebesar $27 \%$.

Tabel 1 Hasil Uji Validitas dan Reliabilitas

\begin{tabular}{cccccc}
\hline Variabel & Indikator & $\begin{array}{c}\text { Pearson } \\
\text { Corelation }\end{array}$ & Validitas & $\begin{array}{c}\text { Cronbach } \\
\text { Alpha }\end{array}$ & Reliabilitas \\
\hline Citra & $\mathrm{X} 1.1$ & 0.912 & Valid & & \\
Koperasi & $\mathrm{X} 1.2$ & 0.937 & Valid & & Reliabel \\
(X1) & $\mathrm{X} 1.3$ & 0.895 & Valid & 0,996 & \\
& $\mathrm{X} 1.5$ & 0.906 & Valid & & \\
\hline
\end{tabular}




\begin{tabular}{|c|c|c|c|c|c|}
\hline & X1.6 & 0.938 & Valid & & \\
\hline & X1.7 & 0.886 & Valid & & \\
\hline \multirow{5}{*}{$\begin{array}{l}\text { Kepercayaan } \\
\text { (X2) }\end{array}$} & $\mathrm{X} 2.1$ & 0.939 & Valid & \multirow{5}{*}{0,950} & \multirow{5}{*}{ Reliabel } \\
\hline & $\mathrm{X} 2.2$ & 0.833 & Valid & & \\
\hline & $\mathrm{X} 2.3$ & 0.949 & Valid & & \\
\hline & X2.4 & 0.936 & Valid & & \\
\hline & $\mathrm{X} 2.5$ & 0.912 & Valid & & \\
\hline \multirow{19}{*}{$\begin{array}{l}\text { Kualitas } \\
\text { Pelayanan } \\
\text { (X3) }\end{array}$} & X3.1 & 0.928 & Valid & \multirow{19}{*}{0,978} & \multirow{19}{*}{ Reliabel } \\
\hline & X3.2 & 0.832 & Valid & & \\
\hline & X3.3 & 0.855 & Valid & & \\
\hline & X3.4 & 0.852 & Valid & & \\
\hline & X3.5 & 0.751 & Valid & & \\
\hline & X3.6 & 0.824 & Valid & & \\
\hline & X3.7 & 0.811 & Valid & & \\
\hline & X3.8 & 0.901 & Valid & & \\
\hline & X3.9 & 0.796 & Valid & & \\
\hline & X3.10 & 0.866 & Valid & & \\
\hline & X3.11 & 0.881 & Valid & & \\
\hline & X3.12 & 0.832 & Valid & & \\
\hline & X3.13 & 0.845 & Valid & & \\
\hline & X3.14 & 0.847 & Valid & & \\
\hline & X3.15 & 0.902 & Valid & & \\
\hline & X3.16 & 0.918 & Valid & & \\
\hline & X3.17 & 0.71 & Valid & & \\
\hline & X3.18 & 0.825 & Valid & & \\
\hline & X3.19 & 0.909 & Valid & & \\
\hline \multirow{7}{*}{$\begin{array}{c}\text { Kepuasan } \\
\text { Anggota (Y) }\end{array}$} & Y1 & 0.949 & Valid & \multirow{7}{*}{0,946} & \multirow{7}{*}{ Reliabel } \\
\hline & Y2 & 0.899 & Valid & & \\
\hline & Y3 & 0.781 & Valid & & \\
\hline & Y4 & 0.833 & Valid & & \\
\hline & Y5 & 0.869 & Valid & & \\
\hline & Y6 & 0.894 & Valid & & \\
\hline & Y7 & 0.875 & Valid & & \\
\hline
\end{tabular}

Sumber : data diolah, 2020

Tabel 2 Karakteristik Responden

\begin{tabular}{lcc}
\hline \multicolumn{1}{c}{ Kategori } & Jumlah (orang) & Persentase (\%) \\
\hline Jenis Kelamin : & & \\
Laki - laki & 20 & 37 \\
Perempuan & 35 & 63 \\
Total & 55 & 100 \\
\hline Umur : & 15 & \\
25-34 tahun & & 28
\end{tabular}




\begin{tabular}{lcc}
\hline \hline & & \\
$35-54$ tahun & 35 & 63 \\
$\geq 55$ tahun & 5 & 9 \\
Total & 55 & 100 \\
\hline Pendidikan : & 7 & 13 \\
SMA/SMK & 18 & 32 \\
DII/DIII & 30 & 55 \\
S1 & 55 & 100 \\
Total & & \\
Masa Menjadi anggota : & 15 & 27 \\
& & 73 \\
$\geq 1$ tahun & 40 & 100 \\
\hline Total tahun & 55 orang &
\end{tabular}

\section{Deskripsi Variabel Penelitian}

Berdasarkan Tabel 3, dapat dilihat bahwa rata-rata skor dari 7 pernyataan mengenai citra koperasi yaitu sebesar 3,48 yang berada di kisaran 3,40-4,20 yang berarti setuju. Namun masih terdapat 20 orang yang menyatakan ragu-ragu terkait pernyataan karyawan telah mengikuti pelatihan sehingga dapat bekerja dengan baik. Walaupun belum optimal, secara keseluruhan citra koperasi selama ini di KSU. Wahyu Artha Sedana bisa meningkatkan kepuasan anggotanya.

Berdasarkan Tabel 4, dapat dilihat bahwa rata-rata skor dari 5 pernyataan mengenai kepercayaan yaitu sebesar 3,39 yang berada di kisaran 2.60-3,40 yang berarti cukup setuju. Dari hasil tersebut dapat dsimpulkan bahwa kepercayaan anggota terhadap KSU. Wahyu Artha Sedana masih tergolong belum maksimal.

Berdasarkan Tabel 5 dapat dilihat bahwa rata-rata skor dari 19 pernyataan mengenai kepercayaan berada di kisaran 3,40-4,20 yang berarti setuju. Dari hasil tersebut dapat dsimpulkan bahwa kualitas pelayanan KSU. Wahyu Artha Sedana terhadap anggotanya sudah ditanggapi positif oleh anggotanya walaupun tergolong ada yang masih ragu-ragu terhadap pernyataan mengenai kualitas pelayanan yang diberikan.

Berdasarkan Tabel 6, dapat dilihat bahwa rata-rata skor dari 7 pernyataan mengenai kepercayaan yaitu sebesar 3,48 yang berada di kisaran 3,40-4,20 yang berarti setuju. Namun masih ada yang memberikan tanggapan cukup setuju terkait pelayanan yang diberikan KSU. Wahyu Artha Sedana.

\section{Tabel 3 Tanggapan Responden Terhadap Variabel Citra Koperasi}

\begin{tabular}{|c|c|c|c|c|c|c|c|}
\hline \multirow{2}{*}{ Pernyataan } & \multicolumn{5}{|c|}{ Skor } & \multirow{2}{*}{$\begin{array}{l}\text { Rata-rata } \\
\text { skor }\end{array}$} & \multirow{2}{*}{ Ket } \\
\hline & 1 & 2 & 3 & 4 & 5 & & \\
\hline $\begin{array}{l}\text { Keberadaan koperasi bermanfaat } \\
\text { bagi anggotanya }\end{array}$ & - & 2 & 19 & 24 & 10 & 3,76 & setuju \\
\hline $\begin{array}{l}\text { Pelayanan usaha membantu } \\
\text { pemenuhan kebutuhan anggota }\end{array}$ & - & 14 & 24 & 14 & 3 & 3,10 & $\begin{array}{l}\text { cukup } \\
\text { setuju }\end{array}$ \\
\hline Ragam produk dapat memenuhi & - & 7 & 20 & 20 & 8 & 3,52 & Setuju \\
\hline
\end{tabular}


kebutuhan anggota

Koperasi dikelola pengurus yang baik

Karyawan telah mengikuti pelatihan sehingga dapat bekerja dengan baik Pinjaman anggota dapat dicairkan bila anggota tersebut memenuhi persyaratan yang diajukan KSU. Wahyu Artha Sedana dapat memenuhi hak anggotanya

\begin{tabular}{|c|c|c|c|c|c|c|c|}
\hline क्. & - & 7 & 22 & 16 & 10 & 3,52 & Setuju \\
\hline $\begin{array}{l}\text { ti pelatihan } \\
\text { engan baik }\end{array}$ & - & 17 & 20 & 17 & 1 & 3,03 & $\begin{array}{l}\text { cukup } \\
\text { setuju }\end{array}$ \\
\hline enuhi & - & 3 & 16 & 23 & 13 & 3,83 & Setuju \\
\hline $\begin{array}{l}\text { na dapat } \\
\text { ja }\end{array}$ & - & 8 & 18 & 17 & 12 & 3,60 & Setuju \\
\hline Jumlah & & & & & & 24,36 & \\
\hline Rata - rata & & & & & & 3,48 & Setuju \\
\hline
\end{tabular}

Sumber : data diolah, 2020

Tabel 4 Tanggapan Responden Terhadap Variabel Kepercayaan

\begin{tabular}{|c|c|c|c|c|c|c|c|}
\hline \multirow{2}{*}{ Pernyataan } & \multicolumn{5}{|c|}{ Skor } & \multirow{2}{*}{$\begin{array}{c}\text { Rata-rata } \\
\text { skor }\end{array}$} & \multirow{2}{*}{ Ket } \\
\hline & 1 & 2 & 3 & 4 & 5 & & \\
\hline Karyawan jujur dalam bekerja & - & 2 & 18 & 19 & 16 & 3,89 & \multirow{5}{*}{$\begin{array}{l}\text { Setuju } \\
\text { cukup } \\
\text { setuju } \\
\text { Cukup } \\
\text { setuju } \\
\text { Cukup } \\
\text { setuju } \\
\text { cukup } \\
\text { setuju }\end{array}$} \\
\hline Pelayanan yang diberikan berkualitas & - & 13 & 19 & 22 & 1 & 3,20 & \\
\hline $\begin{array}{l}\text { KSU. Wahyu Artha Sedana adalah } \\
\text { koperasi yang terpercaya }\end{array}$ & - & 2 & 18 & 18 & 17 & 2,94 & \\
\hline $\begin{array}{l}\text { Karyawan KSU. Wahyu Artha Sedana } \\
\text { adalah orang yang handal dibidangnya }\end{array}$ & - & 13 & 22 & 15 & 5 & 3,21 & \\
\hline $\begin{array}{l}\text { Dana simpanan saya di KSU. Wahyu } \\
\text { Artha Sedana dijamin keamanannya }\end{array}$ & - & 7 & 18 & 15 & 15 & 3,69 & \\
\hline Jumlah & & & & & & 16,93 & \multirow{2}{*}{$\begin{array}{l}\text { Cukup } \\
\text { setuju }\end{array}$} \\
\hline Rata-rata & & & & & & 3,39 & \\
\hline
\end{tabular}

Sumber : data diolah, 2020

Tabel 5 Tanggapan Responden Terhadap Variabel Kualitas Pelayanan

\begin{tabular}{|c|c|c|c|c|c|c|c|}
\hline \multirow{2}{*}{ Pernyataan } & \multicolumn{5}{|c|}{ Skor } & \multirow{2}{*}{$\begin{array}{l}\text { Rata-rata } \\
\text { skor }\end{array}$} & \multirow{2}{*}{ Ket } \\
\hline & 1 & 2 & 3 & 4 & 5 & & \\
\hline Kemudahan tempat parkir & - & 3 & 21 & 16 & 15 & 3,78 & Setuju \\
\hline Kerapian penampilan pegawai & - & 1 & 16 & 27 & 11 & 3,87 & cukup setuju \\
\hline Kenyamanan ruangan & - & 3 & 19 & 23 & 10 & 3,72 & Setuju \\
\hline $\begin{array}{l}\text { Kelengkapan fasilitas fisik yang } \\
\text { dimiliki }\end{array}$ & - & 1 & 20 & 20 & 14 & 3,85 & Setuju \\
\hline $\begin{array}{l}\text { Pelayanan yang diberikan } \\
\text { karyawan cepat }\end{array}$ & - & 10 & 27 & 17 & 1 & 3,16 & cukup setuju \\
\hline Kemudahan prosedur pelayanan & - & 2 & 15 & 27 & 11 & 3,85 & Setuju \\
\hline Pelayanan yang tepat & - & 9 & 28 & 15 & 3 & 3,21 & Cukup setuju \\
\hline $\begin{array}{l}\text { Pelayanan yang selalu siap } \\
\text { menolong }\end{array}$ & - & 3 & 12 & 25 & 15 & 3,94 & Setuju \\
\hline $\begin{array}{l}\text { Tanggap mengatasi keluhan dari } \\
\text { anggota }\end{array}$ & - & 11 & 24 & 16 & 4 & 3.23 & Cukup setuju \\
\hline Informasi yang jelas & - & 2 & 17 & 27 & 9 & 3,78 & Setuju \\
\hline $\begin{array}{l}\text { Kesiapan karywan dalam } \\
\text { memenuhi permintaan anggota }\end{array}$ & - & 2 & 19 & 21 & 13 & 3,81 & Setuju \\
\hline $\begin{array}{l}\text { Ketelitian dalam mencatat setiap } \\
\text { transaksi }\end{array}$ & - & 2 & 19 & 28 & 6 & 3,69 & Setuju \\
\hline
\end{tabular}


Karyawan memiliki pengetahuan yang baik tentang produk yang ditawarkan

Karyawan selalu membina hubungan yang baik dengan anggota

Karyawan kompeten melayani anggotanya

Kepahaman karyawan KSU.

Wahyu Artha Sedana terhadap

kebutuhan anggota

\begin{tabular}{ccccccc}
- & 2 & 21 & 26 & 6 & 3,65 & Setuju \\
& & & & & & \\
- & 2 & 11 & 27 & 15 & 4 & Setuju \\
- & 2 & 19 & 19 & 15 & 3,85 & Setuju \\
- & 5 & 20 & 14 & 16 & 3,74 & Setuju \\
& & & & & & \\
- & 1 & 15 & 34 & 5 & 3,78 & Setuju \\
- & 11 & 22 & 19 & 3 & 3,25 & Cukup setuju \\
- & 4 & 22 & 13 & 16 & 3,74 & Setuju \\
\hline & & & & & 69,99 & Setuju \\
\hline
\end{tabular}

Kesungguhan karyawan KSU.

Wahyu Artha Sedana dalam memperhatikan kepentingan anggota

Karyawan KSU. Wahyu Artha

Sedana selalu sigap ketika amggota meminta pelayanan Perlakuan karyawan kepada anggota sama

\begin{tabular}{l} 
Jumlah \\
\hline Rata - rata \\
\hline Sumber : data diolah, 2020
\end{tabular}

Tabel 6 Tanggapan Responden Terhadap Variabel Kepuasan Anggota

\begin{tabular}{|c|c|c|c|c|c|c|c|}
\hline \multirow{2}{*}{ Pernyataan } & \multicolumn{5}{|c|}{ Skor } & \multirow{2}{*}{$\begin{array}{l}\text { Rata-rata } \\
\text { skor }\end{array}$} & \multirow{2}{*}{ Ket } \\
\hline & 1 & 2 & 3 & 4 & 5 & & \\
\hline $\begin{array}{l}\text { Puas dengan sistem pelayanan } \\
\text { yang diberikan }\end{array}$ & - & 13 & 23 & 17 & 2 & 3,14 & Setuju \\
\hline Karyawan ramah dan sopan & - & 1 & 11 & 27 & 16 & 4,05 & cukup setuju \\
\hline Puas dengan fasilitas yang ada & - & - & 13 & 33 & 9 & 3,92 & Setuju \\
\hline $\begin{array}{l}\text { Pelayanan yang diberikan sama } \\
\text { kepada seluruh anggota }\end{array}$ & - & 4 & 16 & 25 & 10 & 3,74 & Setuju \\
\hline $\begin{array}{l}\text { Saya mengajak anggota keluarga } \\
\text { untuk ikut bergabung di KSU. }\end{array}$ & & & & & & & \\
\hline $\begin{array}{l}\text { Artha Sedana karena saya merasa } \\
\text { puas atas pelayanan yang } \\
\text { diberikan }\end{array}$ & - & 4 & 15 & 24 & 12 & 3,80 & cukup setuju \\
\hline $\begin{array}{l}\text { Karyawan siap dalam melayani } \\
\text { seluruh anggota }\end{array}$ & - & 13 & 21 & 18 & 3 & 3,20 & Setuju \\
\hline $\begin{array}{l}\text { Saya puas telah mendapatkan } \\
\text { keamanan dalam menabung }\end{array}$ & - & 4 & 20 & 18 & 13 & 3,72 & setuju \\
\hline \multicolumn{5}{|l|}{ Jumlah } & & 24,36 & \multirow{2}{*}{ Setuju } \\
\hline Rata - rata & & & & & & 3,48 & \\
\hline
\end{tabular}

Sumber : data diolah, 2020

\section{Uji Asumsi Klasik}

Dari tampilan output SPSS pada Tabel 7 di atas dengan menggunakan uji statistik nonparametrik Kolmogrov-Smirnov (K-S) dapat dilihat bahwa besarnya nilai Sig.2 Tailed adalah 0.713 hal ini berarti H0 diterima yang berarti residual terdistribusi normal $(0.713>0,05)$.

\section{Tabel 7 Hasil Uji Normalitas}




\begin{tabular}{llr}
\hline & & $\begin{array}{c}\text { Unstandardized } \\
\text { Residual }\end{array}$ \\
\hline $\mathrm{N}$ & Mean & 55 \\
Normal Parameters & & $0.00 \mathrm{E}+00$ \\
& Std. Deviation & 3.01295701 \\
Most Extreme Differences & Absolute & 0.094 \\
& Positive & 0.058 \\
& Negative & -0.094 \\
Kolmogorov-Smirnov Z & & 0.699 \\
Asymp. Sig. (2-tailed) & & 0.713 \\
\hline
\end{tabular}

Sumber : data diolah, 2020

Tabel 8 memperlihatkan hasil perhitungan nilai Tolerance menunjukkan tidak ada variabel independen yang memiliki nilai Tolerance kurang dari 0,1 dan nilai Variance Inflation Factor (VIF) juga menunjukkan hal yang sama tidak ada satu variabel independen yang memiliki nilai VIF lebih dari 10. Jadi dapat disimpulkan bahwa tidak ada multikolonieritas antar variabel independen dalam model regresi.

\section{Tabel 8 Hasil Uji Multikolonieritas}

\begin{tabular}{|c|c|c|c|c|c|c|c|c|}
\hline \multirow{2}{*}{\multicolumn{2}{|c|}{ Model }} & \multicolumn{2}{|c|}{$\begin{array}{c}\text { Unstandardized } \\
\text { Coefficients }\end{array}$} & \multirow{2}{*}{$\begin{array}{c}\begin{array}{c}\text { Standardized } \\
\text { Coefficients }\end{array} \\
\text { Beta }\end{array}$} & \multirow[t]{2}{*}{$\mathrm{T}$} & \multirow[t]{2}{*}{ Sig. } & \multicolumn{2}{|c|}{ Collinearity Statistics } \\
\hline & & $B$ & Std. Error & & & & Tolerance & VIF \\
\hline \multirow{4}{*}{1} & (Constant) & 2.848 & 2.473 & & 1.152 & .255 & & \\
\hline & Citra Koperasi & .240 & .093 & .271 & 2.565 & .013 & .641 & 1.560 \\
\hline & Kepercayaan & .417 & .121 & .346 & 3.437 & .001 & .706 & 1.417 \\
\hline & KualitasPelayanan & .135 & .042 & .353 & 3.207 & .002 & .588 & 1.700 \\
\hline
\end{tabular}

a. Dependent Variable: Kepuasan

Sumber : data diolah, 2020

Dari Gambar 2 terlihat bahwa titik-titik menyebar secara acak serta tersebar baik di atas maupun di bawah angka 0 pada sumbu Y. hal ini dapat disimpulkan bahwa tidak terjadi heteroskedastisitas pada model regresi.

\section{Gambar 2}

\section{Hasil uji Heteroskedastisitas}

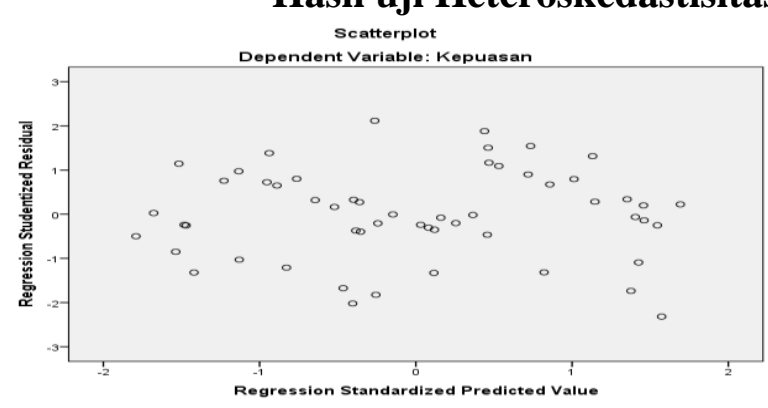




\section{Analisis Determinasi $\left(\mathbf{R}^{2}\right)$}

Berdasarkan hasil output SPSS model summary besarnya nilai $R$ Square adalah 0.636 yang berarti $63,6 \%$ variasi kepuasan anggota dapat dijelaskan oleh variasi dari variabel independen yakni citra koperasi, kepercayaan dan kualitas pelayanan. Sedangkan sisanya (100\% - 63,6\% = 36,4\%) dijelaskan oleh sebab-sebab yang lain diluar model

\section{Tabel 9 Hasil Uji Determinasi $\left(\mathbf{R}^{2}\right)$}

\begin{tabular}{|c|c|c|c|c|}
\hline \multicolumn{5}{|c|}{ Model Summary } \\
\hline Model & $\mathrm{R}$ & R Square & Adjusted R Square & $\begin{array}{l}\text { Std. Error of the } \\
\text { Estimate }\end{array}$ \\
\hline 1 & $.797^{a}$ & .636 & .614 & 3.100 \\
\hline
\end{tabular}

Sumber : data diolah, 2020

\section{Uji Signifikan Parsial (Uji T)}

Uji t dilakukan dengan cara membandingkan nilai statistik t dengan kriteria pengambilan keputusan yaitu membandingan nilai statistik t dengan titik kritis menurut tabel. Uji-T dilakukan untuk menguji Hipotesis $1(\mathrm{H} 1)$, hipotesis $2(\mathrm{H} 2)$, dan hipotesis $3(\mathrm{H} 3)$ yaitu pengaruh citra koperasi, kepercayaan, dan kualitas pelayanan terhadap kepuasan.

\section{Tabel 10 Hasil Uji-T}

\section{Coefficients $^{\mathbf{a}}$}

\begin{tabular}{|c|c|c|c|c|c|c|}
\hline & & Unstar & lardized & Standardized & & \\
\hline Mc & & Coef & cients & Coefficients & $\mathrm{T}$ & Sig. \\
\hline & & B & Std. Error & Beta & & \\
\hline & (Constant) & 2.848 & 2.473 & & 1.152 & .255 \\
\hline & Citra Koperasi & .240 & .093 & .271 & 2.565 & .013 \\
\hline & Kepercayaan & .417 & .121 & .346 & 3.437 & .001 \\
\hline & KualitasPelayanan & .135 & .042 & .353 & 3.207 & .002 \\
\hline
\end{tabular}

a. Dependent Variable: Kepuasan

Sumber : data diolah, 2020

Dari Tabel 10 maka uji parameter individual (uji t) dari tiap variabel $\mathrm{X}$ adalah sebagai berikut :

1. Hasil uji secara parsial diperoleh koefisien regresi sebesar (0.240) dan nilai t hitung untuk citra koperasi sebesar (2.565) dengan nilai signifikan (0.013). Karena nilai signifikan lebih kecil dari 0,05 berarti terdapat pengaruh yang signifikan antara citra koperasi terhadap 
kepuasan anggota KSU. Wahyu Artha Sedana di Gianyar. Hal ini menunjukkan bahwa semakin bagus citra koperasi, maka semakin tinggi kepuasan anggota koperasi.

Hasil penelitian ini selaras dengan penelitian yang dilaksankan oleh Niken Kusdayanti tahun 2016 bahwa citra koperasi berpengaruh positif dan signifikan terhadap kepuasan anggota Koperasi Pegawai Republik Indonesia Setia Kecamatan Mojotengah Kabupaten Wonosobo. Dengan demikian hipotesis yang menyatakan bahwa diduga citra koperasi berpengaruh positif dan signifikan terhadap kepuasan anggota KSU. Wahyu Artha Sedana terbukti kebenarannya.

2. Pengaruh Kepercayaan Terhadap Kepuasan Anggota KSU. Wahyu Artha Sedana Hasil uji secara parsial diperoleh koefisien regresi sebesar (0.417) dan nilai t hitung untuk variabel kepercayaan sebesar (3.437) dengan nilai signifikan (0.001). Karena nilai signifikan lebih kecil dari 0,05 berarti terdapat pengaruh yang signifikan antara kepercayaan terhadap kepuasan anggoota KSU. Wahyu Artha Sedana di Gianyar. Hal ini menunjukkan bahwa semakin tinggi kepercayaan, maka semakin tinggi kepuasan anggota koperasi.

Hasil penelitian ini selaras dengan penelitian yang dilaksankan oleh Penelitian yang dilakukan oleh Heri Setiawan tahun 2016 bahwa kepercayaan berpengaruh terhadap kepuasan anggota. Dengan demikian hipotesis yang menyatakan bahwa diduga kepercayaan berpengaruh positif dan signifikan terhadap kepuasan anggota KSU. Wahyu Artha Sedana terbukti kebenarannya.

3. Pengaruh Kualitas Pelayanan Terhadap Kepuasan Anggota KSU. Wahyu Artha Sedana Hasil uji secara parsial diperoleh koefisien regresi sebesar (0.135) dan nilai t hitung untuk variabel kualitas pelayanan sebesar (3.207) dengan nilai signifikan (0.002). Karena nilai signifikan lebih kecil dari 0,05 berarti terdapat pengaruh yang signifikan antara kualitas pelayanan terhadap kepuasan anggota KSU. Wahyu Artha Sedana di Gianyar. Hal ini menunjukkan bahwa semakin tinggi kualitas pelayanan, maka semakin tinggi kepuasan anggota koperasi.

Hasil penelitian ini selaras dengan penelitian yang dilaksankan oleh Penelitian yang dilakukan oleh Soverani Oktavia dan Tuti Karyani tahun 2017 bahwa kualitas pelayanan berpengaruh positif dan signifikan terhadap kepuasan anggota KPKM (Koperasi Produsen Kopi Margamulya) di Kecamatan Pangalengan. Dengan demikian hipotesis yang menyatakan bahwa diduga kaulitas pelayanan berpengaruh positif dan signifikan terhadap kepuasan anggota KSU. Wahyu Artha Sedana terbukti kebenarannya.

\section{Uji Signifikan Simultan (Uji F)}


Penguji pengaruh variabel independen secara bersama-sama (simultan) terhadap perubahan nilai variabel dependen, dilakukan melalui pengujian terhadap besarnya perubahan nilai variabel dependen yang dapat dijelaskan oleh perubahan nilai semua variabek independen, untuk itu perlu dilakukan uji $\mathrm{F}$ atau Anova

\section{Tabel 11 Hasil Uji Signifikan Simultan (uji F)}

\begin{tabular}{|c|c|c|c|c|c|c|}
\hline \multicolumn{7}{|c|}{ ANOVA $^{a}$} \\
\hline & Model & $\begin{array}{l}\text { Sum of } \\
\text { Squares }\end{array}$ & Df & $\begin{array}{c}\text { Mean } \\
\text { Square }\end{array}$ & $\mathrm{F}$ & Sig. \\
\hline \multirow{3}{*}{1} & Regression & 854.993 & 3 & 284.998 & 29.650 & $.000^{\mathrm{b}}$ \\
\hline & Residual & 490.207 & 51 & 9.612 & & \\
\hline & Total & 1345.200 & 54 & & & \\
\hline
\end{tabular}

Sumber : data diolah, 2020

Hasil uji secara simultan diperoleh nilai F hitung sebesar (29.650) dan dengan nilai signifikan (0.000). Karena nilai signifikan lebih kecil dari 0,05 berarti terdapat pengaruh yang signifikan antara citra koperasi, kepercayaan dan kualitas peayanan terhadap kepuasan anggota KSU. Wahyu Artha Sedana di Gianyar. Penelitian ini selaras dengan penelitian yang dilakukan oleh Niken Kusdayanti tahun 2016 bahwa citra koperasi berpengaruh terhadapa kepuasan Koperasi Pegawai Republik Indonesia Setia Kecamatan Mojotengah Kabupaten Wonosobo, kemudian penelitian yang dilakukan oleh Heri Setiawan tahun 2016 bahwa kepercayaan dan kualitas pelayanan berpengaruh positif dan signifikan terhadap kepuasan nasabah. Dengan demikian hipotesis yang menyatakan bahwa diduga terdapat pengaruh positif dan signifikan secara bersama-sama dari citra koperasi, kepercayaan dan kualitas pelayanan terhadap kepuasan anggota KSU. Wahyu Artha Sedana terbukti kebenarannya.

\section{PENUTUP}

\section{Simpulan}

1. Ada pengaruh citra koperasi terhadap kepuasan anggota KSU. Wahyu Artha Sedana di Gianyar. Hal ini didasari dari koefisien regresi sebesar (0.240) dan nilai t hitung untuk citra koperasi sebesar (2.565) dengan nilai signifikan (0.013). Karena nilai sig. $<0,05$ berarti terdapat pengaruh yang signifikan antara citra koperasi terhadap kepuasan anggota KSU. Wahyu Artha Sedana di Gianyar

2. Ada pengaruh kepercayaan terhadap kepuasan anggota KSU. Wahyu Artha Sedana di Gianyar. Hal ini didasari dari koefisien regresi sebesar (0.417) dan nilai t hitung untuk kepercayaan sebesar (3.437) dengan nilai signifikan (0.001). Karena nilai sig. $<0,05$ berarti 
terdapat pengaruh yang signifikan antara kepercayaan terhadap kepuasan anggota KSU. Wahyu Artha Sedana di Gianyar.

3. Ada pengaruh kualitas pelayanan terhadap kepuasan anggota KSU. Wahyu Artha Sedana di Gianyar. Hal ini didasari dari koefisien regresi sebesar (0.135) dan nilai t hitung untuk kualitas pelayanan sebesar (2.565) dengan nilai signifikan (0.013). Karena nilai sig. $<0,05$ berarti terdapat pengaruh yang signifikan antara kualitas pelayanan terhadap kepuasan anggota KSU. Wahyu Artha Sedana di Gianyar.

4. Ada pengaruh citra koperasi, kepercayaan dan kualitas pelayanan terhadap kepuasan anggota KSU. Wahyu Artha Sedana di Gianyar. Hal ini didasari dari hasil analisis dengan determinasi diperoleh koefisien sebesar 63,6\% berarti variasi pengaruh secara simultan citra koperasi, kepercayaan dan kualitas pelayanan adalah sebesar 63,6\%, sedangkan sisanya sebesar 36,4\% dipengaruhi oleh faktor lain yang tidak diteliti pada penelitian ini. Hal ini juga diuji dengan uji F, dimana diperoleh nilai F-hitung (29.650) dengan nilai signifikan (0.000). Karena nilai signifikan lebih kecil dari 0,05 berarti terdapat pengaruh yang signifikan antara citra koperasi, kepercayaan dan kualitas pelayanan terhadap kepuasan anggota KSU. Wahyu Artha Sedana di Gianyar.

\section{Saran}

1. Berdasarkan hasil penelitian, citra perusahaan berpengaruh terhadap kepuasan anggota, sehingga diharapkan seluruh karyawan memberikan pelayanan sebaik mungkin kepada seluruh anggota maupun nasabah Ksu.Wahyu Artha Sedana. Konsumen yang merasa puas atas pelayanan yang diberikan akan meromendasikan kepada teman atau saudaranya untuk ikut bergabung menjadi nasabah di Ksu. Wahyu Artha Sedana.

2. Kepercayaan berpengaruh secara positif dan signifikan terhadap kepuasan anggota koperasi, maka sebaiknya seluruh pihak ataupun karyawan KSU. Wahyu Artha Sedana menjalin hubungan yang baik dengan semua nasabah dengan cara memberikan pelayanan semaksimal mungkin agar nasabah menjadi yakin dan percaya bahwa Ksu. Wahyu Artha Sedana merupakan koperasi yang selalu mengutamakan kepentingan anggotanya.

3. Kualitas pelayanan berpengaruh terhadap kepuasan anggota Ksu. Wahyu Artha Sedana, maka dari itu sudah selayaknya mempertahankan dan bila memungkinkan untuk ditingkatkan lagi terkait kualitas pelayanan sehingga kepuasan anggota dapat ditingkatkan agar anggota yang sudah ikut bergabung di koperasi maupun calon nasabah akan semakin bertambah untuk membantu kesejahteraan dan kelancaran arus keuangan di KSU. Wahyu Artha Sedana. Apaila anggota koperasi sudah merasa puas terhadap pelayanan maka secara tidak langsung citra 
koperasi akan menjadi baik dan anggota menjadi percaya untuk melakukan transaksi di KSU. Wahyu Artha Sedana.

4. Bagi penelitian selanjutnya, oleh karena pada hasil penelitian ini masih ada faktor lain yang mempengaruhi kepuasan anggota maka diharapkan untuk menggunakan variabel lainyang berpengaruh terhadap kepuasan anggota dan diharapkan untuk menambah jumlah sempel penelitian

\section{DAFTAR PUSTAKA}

Adenk Sudarwanto.2013.Akuntansi Koperasi. Yogyakarta: Graha Ilmu Anggoro Lingga.M. 2002. Teori dan Profesi Kehumasan. Jakarta. Bumi Aksara. Avanza Jurnal EMBA. Vol.1 No.3, September 2013, p.1251-1259

Ardianto, Elvinaro.2016. Metodologi Penelitian Untuk Public Relations. Bandung: Simbiosa.

Ghozali, Imam. 2011. "Aplikasi Analisis Multivariate Dengan Program SPSS". Semarang: Badan Penerbit Universitas Diponegoro.

Ghozali, Imam. 2013. Aplikasi Analisis Multivariate dengan Program IBM SPSS 21 Update PLS Regresi. Semarang: Badan Penerbit Universitas Diponegoro. Hendar.2010. Manajemen Perusahaan Koperasi. Jakarta: Erlangga.

Heri Setiawan dan Maria Magdalena Minarsih. 2016. Pengaruh Kualitas Produk, Kualitas Pelayanan dan Kepercayaan Terhadap Kepuasan Nasabah Dan Loyalitas Nasabah Dengan Kepuasan Sebagai Variabel Intervening ( Studi Kasus Pada Nasabah Koperasi Rejo Agung Sukses Cabang Ngaliyan ) Journal Of Management. Volume 2 No.2 Maret 2016

Husein Umar. (2005), Metode Penelitian Untuk Tesis Dan Bisnis, Jakarta: Grafindo Persada.

Irawan. 2005. Asas-asas Marketing. Liberty: Yogyakarta

Istijanto, 2005.Aplikasi Praktis Riset Pemasaran. Jakarta : PT Gramedia Pustaka Utama

Jefkins, Frank. 2003. Public Relations Edisi kelima, Jakarta: PT Gelora Aksara Pratama

KBBI, 2016. Kamus Besar Bahasa Indonesia (KBBI). [Online] Available at: http://kbbi.web.id/pusat, [Diakses 21 Juni 2016].

Kementerian Koperasi dan Usaha Kecil dan Menengah Republik Indonesia. Available online at http://www.depkop.go.id/ (Diakses tanggal 5 agustus 2019)

Koperasi dan Usaha Kecil Menengah Pemerintah Kabupaten Bandung. Available online at www.koperasi.bandungkab.go.id (Diakses tanggal 6 agustus 2019)

Kotler, Philip 2003. Manajemen Pemasaran. Jilid 1. Jakarta : penerbit Erlangga . 2009. Manajemen Pemasaran. Jakarta: Erlangga.

Kotler, P., Armstrong, G. 2008. Prinsip-Prinsip Pemasaran. Edisi 12. Jilid 1. Jakarta: Erlangga. 2014. Prinsip-prinsip Manajemen. Edisi 14, Jilid 1. Jakarta: Erlangga

Kotler, P. \& Keller, K.L. (2012), Manajemen Pemasaran Jilid I Edisi ke 12. Jakarta: Erlangga

Lovelock, Christoper dan Jochen Wirtz. 2011. Service Marketing. New Jersey USA: Pearson

Moh Nazir. 2003. Metode Penelitian. Jakarta : Ghalia Indonesia, 2003. 
Niken Kusdayanti.2016. Pengaruh Citra Koperasi dan Kualitas Pelayanan terhadap Kepuasan Anggota Koperasi Pegawai Republik Indonesia Setia Kecamatan Mojotengah Kabupaten Wonosobo, niken kusdayanti fakultas ekonomi, universitas negeri Yogyakarta. Vol. 5, Nomor2, Tahun 2016

Noor. Juliansyah, 2011, Metodologi Penelitian, Prenada Media Group, Jakarta

Pemerintah Kota Medan. Undang-undang Nomor 25 Tahun 1992 Tentang Perkoprasian, Available online at www.diskopumkm.pemkomedan.go.id (Diakses tanggal 5 agustus 2019)

Pusat Bahasa. 2008. KBBI Daring, Kamus Besar Bahasa Indonesia. Jakarta: Pusat Bahasa Depdiknas RI, http://pusatbahasa.diknas.go.id. Diunduh tanggal 20 Mei 2010.

Ratna Dewi Ekawati.2016. Pengaruh Citra, Pelayanan dan Kepuasan Terhadap Loya;itas Anggota Pada Koperasi Wanita Persada Mandiri Salatiga, ISSN 2252-6544

Rangkuti, Frendy. 2006. Riset Pemasaran. Gramedia Pustaka Utama: Jakarta

Ridwan, 2003, Skala Pengukuran Variabel-variabel Penelitian, Penerbit Alfabeta, Bandung.

Rudianto. 2013. Akuntansi Manajemen Informasi untuk Pengambilan Keputusan Strategis. Jakarta: Erlangga.

Sugiyono 2001, Metode Penelitian Administrasi, Bandung, Penerbit Alfabeta ,2004, "Metode Penelitian Bisnis", Alfabeta, Bandung.

. 2008. Metode Penelitian Kuantitatif Kualitatif dan R\&D. Bandung Alfabeta.

. 2010. Metode Penelitian Pendidikan Pendekatan Kuantitatif, kualitatif, dan R\&D. Bandung: Alfabeta

.2011.Metode Penelitian Kuantitatif dan Kualitatif dan R \& D. Bandung: CV Alfabeta.

.2013.Metode Penelitian Pendidikan Pendekatan Kuantitatif, Kualitatif, dan R\&D. Bandung: Alfabeta

Susiyanti Asim. 2017. Pengaruh Citra Koperasi dan Kualitas Pelayanan Terhadap Kepuasan Anggota Koperasi Karyawan Rumah Sakit Anak dan Bunda (RSAB) Harapan Kita Jakarta. Vol. 10, No. 2, Desember 2017 ISSN : 16936876.

Shandy Marsono dan Endah Nawangsasi. 2018. Pengaruh Kualitas Pelayanan Terhadap Kepuasan Anggota Koperasi Dosen dan Karyawan AUB Pancasila Surakarta (STIE Adi Unggul Bhirawa) ISSN: 1412-8837 Vol 3. No. 22018 ISSN 2579 - 5597

Soverani Oktavia dan Tuti Karyani. 2017. Pengaruh Kualitas Pelayanan Terhadap Kepuasan KPKM (Koperasi Produsen Kopi Margamulya) di Kecamatan Pangalengan , Program Studi Agribisnis Universitas Padjadjaran, AGRISEP Vol. 16 No. 2 September 2017 Hal: 155 - 164| 155

Sutisna. 2001. Perilaku Konsumen dan Komunitas Pemasaran. Bandung: PT Remaja Rosdarkarya

Tjiptono, Fandy. 2002. Manajemen Jasa. Yogyakarta: Andi Offset. . 2011.Manajemen Jasa. Yogyakarta: Andi Offset. . 2012. Manajemen Jasa. Malang : Yogyakarta: Andi Offset. 
. 2014. Pemasaran Jasa (Prinsip, Penerapan, Penelitian). Yogyakarta: Andi Offset.

Tasunar, Nanang. 2006. Kualitas Layanan Sebagai Strategi Menciptakan Kepuasan pada Pangkalan Pendaratan Ikan (PPI) Morodemak. .2005. Pemasaran Jasa. Malang: Bayumedia Publishing Jurnal Sains Pemasaran Indonesia. Vol. 5, No. 1

Tim Prima Pena. 2006. Kamus Besar Bahasa Indonesia. Jakarta: Gita Media Press.

Uma Sekaran, 2006, Metodologi Penelitian untuk Bisnis, Edisi 4, Buku 1, Jakarta: Salemba Empat. 